\title{
IMPACT OF IGNORANCE OF CUSTOMER QUERIES BY RETAILER SALES STAFF ON CUSTOMER PURCHASE DECISION
}

\begin{abstract}
Afnan Ali ${ }^{1}$
ABSTRACT

This research is based on a description of the impact of ignorance of customer queries by retail sales staff on customer purchase decisions. This study is a questionnaire-based survey, and the analysis of the questionnaire and literature review is used to derive the conclusions. The outcomes of this research have revealed that the impact of ignorance of customer queries by retail sales staff has a positive correlation with the customer purchase decision. This research has described the impact of ignorance of customer queries by retailer sales staff through four constructs including customer satisfaction, customer trust, salesperson personality and purchase intention. The fact is when we define something as being important, we do everything possible to achieve it, and this is often related to the acquisition of some good. Even if your niche does not directly involve some personal purpose of your persona, it can do so in an indirect way, and if well explored, this concept can be very lucrative. Daily decisions are made on a day-to-day basis, although this decision-making process is hardly thought of. For marketing, this process, through the understanding of the customer buying decision process, is fundamental, since it allows the planning of better marketing strategies, contributing to a greater success of the brands. The concluding remarks of this research can be used as an information reference for the marketing managers, industrialists, and business-oriented people.
\end{abstract}

Keywords: Customer Queries; Purchase Intention; Retailers; Salesperson's Engagement; Purchase Decision; Customer Satisfaction.

\footnotetext{
${ }^{1}$ Iqra University, Karachi, Pakistan. Email: afnaniu86@gmail.com
} 


\section{INTRODUCTION}

The essential problem in research on customer behaviour is perception, investigation and number of the qualities that impact customers in making the purchase decisions, keeping in mind that the behaviour of customer choice is directly linked with the services. The end goal is to provide a better environment for the customer. We are living in the era of technology where almost everything is sold and purchased through the internet, but we cannot ignore the importance of direct selling. Direct selling also has its importance in which salesperson personality plays a vital role in order to get more market competitive advantages. The salesperson's success depends upon how they deal with the customers. In case they ignore any customer for whatever reason imply, maybe they are overworked or maybe are underpaid. Ultimately these matters affect the business, and they may lose their potential customers.

The customer is undoubtedly considered to be the core focus of almost every organization. With a specific end goal to make a due share in the market, the client is the main single concern of any organization. The more the organization has its customer's satisfaction, the more noteworthy is the possibility of survival for an organization in the market. The vast majority of organizations close down in the event that they cannot comprehend the needs of their clients. Thus, market orientation has deep rooted its presence and importance in global business systems.

At Present, new organizations can be seen making their place in the market, as the number of ventures is rapidly expanding. Each business has a specific target market of the customer. Accordingly, if a business intends to expand into similar ventures with a similar target market and customer needs, the businesses then need to confront competition and resistance. The review demonstrates that there is an immense distinction between the customer needs and organizational offerings especially in the service sector due to rapidly increasing cutthroat competition between perfectly competitive firms (Berry, 2002).

In the service sector, where the salespersons have direct contact with the customers, modesty in dealing with people plays a vital role in winning customers. If the salespersons are glad about their job, they put extra effort to win customer trust and impact their purchase decisions. In addition, care for customers and their attitudes are the fundamental traits of a salesperson which bring positivity to the customer-salesperson relationship. The attributes relating to responsible sales personal include obligation, duty, and job dependability. Exceptionally cognizant salespersons work diligently to acquire client's attention, attract them towards store offerings and alter their 
impulsive purchase decisions. Another attribute concerned with a salesperson's personality trait is accomplishment, in which people concentrate profoundly on accomplishing objectives and measure persistent execution when contrasted with their objectives. In this quality, $84 \%$ of salespeople try to reach the exceptional achiever status. Similarly, it is observed that the customers usually make incessant inquiries, and acquire business or product knowledge, the salesperson thus needs to focus on knowing the client observations. Salespersons attributes also include sociability that implies inclination toward individuals and neighborliness (Loveland et al., 2015).

In order to encourage the customer's choice process, retailers usually provide shopping help or suggestions, for example, customized item suggestions and item evaluative data (i.e., item appraisals). This shopping helps demonstrate potential item answers for the customer, help limit conceivable alternatives, and in addition control the buyer to decide their purchase among the top recommendations (Payne, Bettman, \& Johnson, 1993). Given the common routine of furnishing customers with customized item details and evaluative data (particularly in a web-based shopping setting), it is critical to comprehend under what conditions shoppers will probably choose to finish a buy a product, subsequently, if the data given by this arrangement involves physical shopping, it helps product knowledge acquisition.

Buyers with restricted or no earlier item information may experience issues evaluating the advantages of the chosen product, and on buying choices (Alba \& Hutchinson, 1987). An immediate brand-to-objective affiliation, while making a difference between them sidestep the muddled points of interest including brand property convictions, product characteristic, significance, and objective affiliations (Huffman \& Houston, 1993). Previous research demonstrates that the respondents probably pick a prescribed alternative when they are confronted with a troublesome decisional task. Low information buyers will probably see a choice undertaking as confounded on the grounds as they are not able to fathom, dissect, and expand product determination data (West, Brown, \& Hoch, 1996). Subsequently, they are probably going to depend on customized item suggestions directed to them as a solution to decision instability and to avoid choice delay.

Thus, in light of the above literature scope and significance, it has been deduced that customersalesperson relationship plays a pivotal role in sales increment. The main purpose of this study is hence to find out the impact of ignorance of customer queries by retailer sales staff on the customer purchase decisions. Choices have always been synonymous with freedom. But the more complex 
and frequent the decisions we make, the more exhaustive they are. Therefore, it is an organization's salespersons responsibility to facilitate as much as possible the process of choice that involves their product or service offerings.

\section{RESEARCH QUESTIONS}

The present study will investigate the following research questions.

- Is there any impact of customer purchase decision due to the salesperson's personality?

- Is there any impact of customer purchase decision due to customer-organization trust?

- Is there any impact of customer purchase decision on customer satisfaction?

- Is there any impact of customer purchase decision on the customer purchase intention?

\section{LITERATURE REVIEW}

\section{Underpinning and Supporting Theories/Models}

Even though the themes of manageableness and natural purchase intentions can be discussed, it is critical to first comprehend the act of customers decision process. There are a few complex models of customer basic decision making and buyer leadership. Svenson (1995) condense nine such models, all comprising of various process steps. Given the multifaceted nature of buyer leadership, diverse researchers have concentrated on distinctive aspects. A few researchers inspected the impact of characteristics of customers, for example, their way of life, shopping style and general customer identity on basic leadership (Cowart \& Goldsmith, 2007), whereas other emphasized on basic leadership styles and communication of item advantages and choice modes (Gaston-Breton \& Duque, 2015). It is furthermore fundamental to comprehend the nature of shopper's leadership desirability (Thogersen, Jorgensen, \& Sandager, 2012), such as their reaction to 'green' products. Studies found that most customers like purchasing organic and green products while some customers were enticed to buy non-organic due to their likeableness, lifestyle, desirability, and due to utilization of their own unique heuristics. Heuristics are techniques or methods customers use to make rational decisions and judgments about purchase decisions (Bettman, Luce, \& Payne, 1998).

Shoppers tend to apply exceptionally basic determination guidelines or strategies that help them make an acceptable decision while approving a rapid choice. This sort of strategy is alluding to heuristics (Hoyer, 1984). In addition, heuristics can be cognizant or oblivious to basic leadership procedures that shoppers use to spare time and lessen confusion in individual decision 
circumstances (Gigerenzer\& Brighton, 2009). Previous literature proposes that buyers utilize this idea of heuristics particularly when they need to browse an expansive arrangement of choices. Retailers are anxiously furnishing clients with various shopping helps, characterized as "shopping help conveyed by retailers encourage shopping encounters and expand buyers' impulsive purchases". Retailers today convey buying help not only through onsite salespersons but through newest technology such as websites, booths, handheld gadgets, and PC empowered basic supply gadgets to convey shopping help, for example, giving customized item proposals by means of a calculation or giving extra item data upon shoppers asking, among others. While the administrative instinct proposes that shoppers ought to benefit by the help furthermore, this practice helps eliminate the rejection chances of an item in retail shopping as examination of the product before buying is tended to the buyer. By looking at regardless of whether and how buyers' advantage from utilizing the retail shopping help, in particular, researchers look at the viability of shopping help in supporting customer choice settling and improving their buying choice fulfilment (Todd \& Gigerenze, 2000).

\section{Empirical Reviews}

Salespersons' personality characteristics are considered imperative to calculate buyer-seller associations. Research studies found some identity attributes and presumptions valid and viewed more suitable for a sales deal (Barrick, Stewart, \& Piotrowski, 2002). Similitudes in seller/buyer personalities or characteristics prompt positive result in sales deals. Our exploration, accordingly, incorporates the measure of big five personality traits, used to look at the impact of personality on the sales representative's nature' and associations with their companions and clients.

The buyers nowadays do not believe seller focused tactics or helps and do not consider them to be truthful. The level of significance in trust of is additionally bolstered by dedication and sincerity (Chaudhuri \& Holbrook, 2001), as it creates credibility in relationships (Rod \& Ashill, 2010).

\section{Research Framework}

Having different personality traits, attitudes and characteristics, all salespersons are not equally effective although given similar arrangements, tools, training, and work. A few salespersons surpass success while other even cannot meet the minimum sales threshold. The studies propose that the personalities of the extraordinary sales representatives intends to be a basic part in determining their success (Crosby \& Evans, 1990). The sellers who participate in creating rapport and showcase care and credibility create relationship associations. The nature of connections 
between the clients and salespersons forms the prospect of continued business relationship (Lawrence, Evans, \& Cowles, 1990). In this manner, designating the correct salesperson for the administration of particular business networks is extremely essential for organizations. The individual personality qualities are crucial components of the buyer seller relationship as the buyer seller connections generally require continuous negotiations on price, quantity, delivery, purchase terms, and product features. This process may involve connection between necessities and conflicting interests. In this way, the personality of a salesperson influence in dealing with the relationship, along these lines affect a customer's perceptions about the nature of dispensation given by the sales representative (Dion, Easterling, \& Miller,1995), thus us thus considered as on the most exceptional assumptions which clarifies why clients remain faithful to particular retail stores (Thibaut \& Kelley, 1959). Because of its exceptional personification, research articulates that people keep a link due to the quality of engagement. In a perfect world, customization prevents substitution and builds the appeal of the business relationship in contrast to diverse available alternatives. Initially, customization requires a common endeavor into the business relationship. Customers devote energy and exertion communicating their wants and desires, whereas its upon businesses to consider their demands and produce products according to their requirements in a competitive market economy. The business relationship representatives establish connectionspecific resources that are categorically associated to emphatic networks (Levinthal\& Fichman, 1988).

The goal to acquire customer retention and repeat sales as be characterized by catering individual customized demands (Hausman \& Siekpe, 2009). If the customer specific demand is not catered even for once, in retail business it creates a massive setback and towards losing customer trust Supphellen \& Nysveen, 2001). Thus, customers' image assessment and credibility for retail store plays a crucial role in customer retention and repeat visits.

Customer satisfaction has been of considerable interest to marketing professionals and experts alike (Darke, Ashworth, \& Main, 2010). The predominant view is that customers encounter satisfaction or dissatisfaction with purchase decision and purchase choice (Fitzsimons, 2000). Customer satisfaction with the selection process has been observed to be a significant advocate of customers' by and large satisfaction decisions. Product availability, pre-purchase information, product valuation and assessment of satisfaction/dissatisfaction have a significant impact on purchase decision (Westbrook, Newman, \& Taylor, 1978). Heitmann, Lehmann, and Hermann, 
2007 suggest that demand satisfaction is determined by the customer's achievement of decision objectives, for example, decision confidence, low uncertainty, and lower prices. Despite adding to purchase satisfaction positively affects loyalty and ability to recommend the product to others and is henceforth hypothetically and observationally validated. Similarly, customization reduces customer uncertainty and vulnerability which establishes customer's trust (Moorman, Deshpande, \& Zaltman, 1993). A few experimental studies have affirmed a huge impact of customization on customer loyalty (Coulter \& Coulter, 2002). Some observational reviews found that the apparent ability of organizations to create credibility is through building trust relationship (Doney \& Cannon, 1997).

\section{RESEARCH HYPOTHESES}

H1:There is a significant impact of salesperson's personality on the customer purchase decision.

H2:There is a significant impact of customer's trust on the customer purchase decision.

H3: There is a significant impact of customer satisfaction on the customer purchase decisions.

H4: There is a significant impact of purchase intention on the customer purchase decisions.

\section{RESEARCH METHODOLOGY}

\section{Research Approach}

A quantitative approach is used to collect the data on the impact of ignorance of customer queries by retailer sales staff on the customer purchase decision. To gather data from 300 respondents a survey technique was utilized. This approach falls under the branch of rationality called positivism that works according to forecasts, laws, truth, and rigorous logical rules. Quantitative analyses assert that fact is always supreme, and the truth could be given a thoughtful estimation. Keeping in mind the end goal to look through reality, a researcher should set aside his own biases, beliefs, sentiments, and judgments in a way that does not affect the research process.

\section{Research Design}

Research design is related to the strategies applied for data analysis. In this research, which contains test determination, the procedure of inspecting, information gathering instrument, number of members, factual approach and research legitimacy that is utilized for information investigation. This part speaks to the entire diagram of the exploration strategies utilized to drive applicable 
information investigation. To investigate the impact of ignorance of customer queries by retailer sales staff on customer purchase decision One-Sample T-Test examination has been performed. Along these lines, the information has been gathered from 200 respondents with the goal that the method of details can make legitimate and solid results. The legitimacy and dependability test will be performed to check the effectiveness of the strategies and the estimation of essentialness is utilized to check unwavering quality and legitimacy.

\section{Sampling Design}

In this research, we use the convenience sampling technique. In the structural equation model (SEM) there is Amos and Pls. we are using Amos and in Amos, we have to take 300 respondents. That is why we are taking 300 respondents in our research. Keeping in mind the end goal to get nonpartisan reactions from the members a non-probabilistic arbitrary examining procedure is utilized as a part of this examination. The primary favorable position of utilizing this strategy is impartial and clear result of the examination. Another preferred standpoint of this strategy is that it gives level equal chance to all members to put their perspectives in answers to the survey. The sampling data is collected from different satisfied customers. For this research, the sample size of respondents is 300 that have been selected from students at different universities from Karachi, Pakistan who have experiences of purchasing at retail outlets.

\section{Instrument of Data Collection}

In this research, the method for collecting data is done through a questionnaire. The quantitative method is used because in this research we are measuring customer behaviour. The questionnaire analysis method is used for the purpose of research about the impact of ignorance of customer queries by retailer sales staff on the customer purchase decision. The consequences of evaluation in which information is gathered from the survey and also different sources investigated by methods for programming and present them in this manner. The quantitative research approach is utilized where the client is meaning a measurable approval of speculation denied of dissecting the inspirations driving the reactions. Then again, to gather more material for the examination a subjective technique is likewise utilized where information is gathered from books, articles, diaries, databases, and magazines.

\section{Validity and Reliability Test}

The validity and reliability test will be performed to check the effectivity of the methods and the value of significance is used to check reliability and validity. The data is $60.3 \%$ reliable. 
Reliability Statistics

\begin{tabular}{|r|r|}
\hline Cronbach's Alpha & N of Items \\
\hline .603 & 15 \\
\hline
\end{tabular}

\section{The procedure of Data Collection}

The survey approach is utilized to gather information from various participants as far as the Likert scale was utilized for addressing the framework. The auxiliary based information is gathered to give confirm in writing audit keeping in mind the end goal to legitimize the investigation discoveries. The primary concentrate of the examination is on the information gathering performed through a quantitative approach as a poll.

\section{Statistical Technique}

The procedure of data analysis alludes to the strategies and systems that are utilized to dissect information gathered in the investigation to infer important results and data. There is an assortment of information examination procedures in which the most reliable and popular strategies are measurable systems. The primary advantage of factual strategies is that they are exceptionally irrefutable. In this examination, spellbinding measurements and relapse investigation has been led utilizing SPSS. As the survey depends on 5-point Likert's Scale, in this manner, the nearby finished inquiries have been exhibited. Factor examination has been utilized to procure information about the fundamental developments. A short time later, the normal score of those builds has been utilized to investigate the effect mark advancement on mark faithfulness utilizing the Regression T-Test.

\section{RESULTS AND FINDINGS}

\section{Descriptive Profile of the Data}

The Table given below is the model summary table which reflects the aftereffect of data and showing the values of $\left(\mathrm{R}=45.5 \%, \mathrm{R}^{2}=20.7 \%\right.$, Adjusted $\mathrm{R}^{2}=19.5 \%$, and $\left.\mathrm{S} . \mathrm{E}=59.1 \%\right)$ independent variable when analyzing dependent variable which was customer purchase decision. The value of $R$ displays the average correlation which was $45.5 \%$. The value of $R^{2}$ indicates to what degree of the data is close to the line of regression, so from the analysis, it was observed 
$20.7 \%$ can be described. The value of adjusted $\mathrm{R}^{2}$ indicates actual data closeness so $19.5 \%$ was observed. And finally, the S.E standard so $59.1 \%$ was the estimated distance.

Table 1. Model Summary

\begin{tabular}{|l|r|r|r|r|}
\hline Model & \multicolumn{1}{|c|}{$\mathrm{R}$} & \multicolumn{1}{|c|}{ R Square } & Adjusted R Square & \multicolumn{1}{c|}{$\begin{array}{c}\text { Std. Error of the } \\
\text { Estimate }\end{array}$} \\
\hline 1 & $.455^{\mathrm{a}}$ & .207 & .194 & .59100 \\
\hline
\end{tabular}

a. Predictors: (Constant), Purchase_Intention, Customer_Trust,

Customer_Satisfaction,SSalesperson_Personality

b. Dependent Variable: Customer_Purchase_Decision

After observing the (ANOVA) Analysis of Variance in the table given below so it was discovered that $(<0.05)$ level of significance and this was the linear relationship between variables, and also the validation of the overall model and the values $(\mathrm{F}=15.983)$ describe that model of customer purchasing model was average fitted.

Table 2. ANOVA ${ }^{b}$

\begin{tabular}{|rr|r|r|r|r|r|}
\hline Model & & Sum of Squares & df & Mean Square & F & \multicolumn{1}{c|}{ Sig. } \\
\hline 1 & Regression & 22.330 & 4 & 5.583 & 15.983 & $.000^{\mathrm{a}}$ \\
& Residual & 85.574 & 245 & .349 & & \\
& & & & & \\
& Total & 107.904 & 249 & & & \\
\hline
\end{tabular}

a. Predictors: (Constant), Purchase_Intention, Customer_Trust, Customer_Satisfaction,

Salesperson_Personality

b. Dependent Variable: Customer_Purchase_Decision

The table given below is the coefficient that summarizes the regression equation's aftereffects. In the table, segment B gives an estimation of the regression consistent and coefficients. Therefore, it was observed that "customer purchase decision " which was a dependent variable all the variables are equal to zero. In the coefficient table, at the same time as studying the independent variables' estimations the values of Beta (where customer satisfaction $=2 \%$, salesperson personality $=37.3 \%$ customer trust $=-8 \%$ and purchase intention $=4 \%$ ). The section Beta values examine the degree to which the independent variable's estimation sum up the dependent variable's 
estimation. After the analysis, it was observed that two variables are higher than or greater than 2 which is the "T value" which defines those variables that are independent contributors to the dependent variables. While studying values of "T" (where customer satisfaction= 0.386 , salesperson personality $=5.049$, customer trust $=-2.357$ and purchase intention $=.617$ ). Except for customer satisfaction and purchase intention remaining variables were accepted since sig value $(<0.05)$.

Table 3. Coefficients ${ }^{\mathrm{a}}$

\begin{tabular}{|c|c|c|c|c|c|c|c|}
\hline \multirow[b]{2}{*}{ Model } & \multicolumn{2}{|c|}{$\begin{array}{c}\text { Unstandardized } \\
\text { Coefficients }\end{array}$} & \multirow{2}{*}{$\begin{array}{c}\text { Standardized } \\
\text { Coefficients }\end{array}$} & \multirow[b]{2}{*}{$\mathrm{t}$} & \multirow[b]{2}{*}{ Sig. } & \multicolumn{2}{|c|}{$\begin{array}{l}\text { Collinearity } \\
\text { Statistics }\end{array}$} \\
\hline & B & Std. Error & & & & Tolerance & VIF \\
\hline (Constant) & 2.390 & .340 & & 7.028 & .000 & & \\
\hline Customer_Satisfaction & .025 & .066 & .027 & .386 & .700 & .682 & 1.467 \\
\hline Salesperson_Personality & .373 & .074 & .352 & 5.049 & .000 & .667 & 1.500 \\
\hline Customer_Trust & -.081 & .034 & -.144 & -2.357 & .019 & .862 & 1.160 \\
\hline Purchase_Intention & .041 & .066 & .043 & .617 & .538 & .667 & 1.499 \\
\hline
\end{tabular}

a. Dependent Variable: Customer_Purchase_Decision

\section{Hypotheses Assessment Summary}

\begin{tabular}{|c|l|c|c|}
\hline S. No & \multicolumn{1}{|c|}{ Hypotheses } & T-Value & Empirical Conclusion \\
\hline 1 & $\begin{array}{l}\text { There is a significant effect of sales personality on customer } \\
\text { purchase decision }\end{array}$ & 5.049 & Accepted \\
\hline 2 & $\begin{array}{l}\text { There is a significant effect of customer trust on customer } \\
\text { purchase decision }\end{array}$ & -2.357 & Accepted \\
\hline 3 & $\begin{array}{l}\text { There is a significant effect of customer satisfaction on the } \\
\text { customer purchase decision. }\end{array}$ & 0.386 & Rejected \\
\hline 4 & $\begin{array}{l}\text { There is a significant effect of purchase intention on customer } \\
\text { purchase decision }\end{array}$ & .617 & Rejected \\
\hline
\end{tabular}




\section{CONCLUSION}

In conclusion, it can be said that it is just not an appropriate word, but it is a formula for the company to respect the client, and also to assist them in a "timely manner". If you pay your employees for the time they spend on the company, it is essential to understand that time for everyone is valuable and cannot under any circumstances, the organizations can waste clients time by requiring them to wait for long to address their queries. It is evident that disregarding client's satisfaction, ends in losing them which is also a case due to tedious communication attempts. Even long trips to the outlets and centers and to wait there patiently should be taken care of and considered to improve the client-sales relationship. From the results, it was concluded that there is a significant effect of salesperson's personality and trust, on customer purchase decision which provides useful insights to the marketing managers in the retail business, to devise appropriate strategies related to customer satisfaction and trustworthiness.

\section{DISCUSSION}

The interesting thing about this research is that it advances the understanding of the protection of customer rights and highlights the role of the service provider. The rude or unreceptive behaviour of salespersons is the disrespectful treatment of the client, subjecting them to experience an unpleasant situation that imposes damaging impressions on the organization's image, customer satisfaction, customer loyalty and organizational sales. The ruling warns that the disrespectful behaviour comes from the excessive delay in the attention and lack of decorum in the treatment of the employee towards the client, evident through high tone of voice and dislike in meeting the requirements as well as the lack of collaboration (all of which was proven through testimonials).

\section{RECOMMENDATIONS}

It is prescribed for the administration officials to outline certain policies that advance in marking customer relationship development. It is important to deliver respectful behaviour that can get the consideration of customers. It is recommended for retails sales staff to deal with customers with complete attention and cater to their queries to influence their purchase decision. Similarly, it is suggested that organizations should have user-friendly technologies for employees so that each employee has command over it without any hassle and they should be trained appropriately. In the longer run, these strategies can bring forth positive results for organizations and increase customer trust which may result in greater sales. 


\section{REFERENCES}

Alba, J. W., \& Hutchinson, J. W. (1987). Dimensions of Customer Expertise. Journal of Customer Research, 13(4), 411. https://doi.org/10.1086/209080

Barrick, M. R., Stewart, G. L., \& Piotrowski, M. (2002). Personality and job performance: Test of the mediating effects of motivation among sales representatives. Journal of Applied Psychology, 87(1), 43-51. https://doi.org/10.1037/0021-9010.87.1.43

Bettman, J., Luce, M., \& Payne, J. (1998). Constructive Customer Choice Processes. Journal of Customer Research, 25(3), 187-217. https://doi.org/10.1086/209535

Chaudhuri, A., \& Holbrook, M. B. (2001). The Chain of Effects from Brand Trust and Brand effect to Brand Performance: The Role of Brand Loyalty. Journal of Marketing, 65(2), 81-93. https://doi.org/10.1509/jmkg.65.2.81.18255

Coulter, K. S., \& Coulter, R. A. (2002). Determinants of trust in a service provider: the moderating role of length of the relationship. Journal of Services Marketing, 16(1), 35-50. https://doi.org/10.1108/08876040210419406

Cowart, K. O., \& Goldsmith, R. E. (2007). The influence of customer decision-making styles on online apparel consumption by college students. International Journal of Customer Studies, 31(6), 639-647. https://doi.org/10.1111/j.1470-6431.2007.00615.x

Crosby, L. A., Evans, K. R., \& Cowles, D. (1990a). Relationship Quality in Services Selling: An Interpersonal Influence Perspective. Journal of Marketing, 54(3), 68-81. https://doi.org/10.1177/002224299005400306

Crosby, L. A., Evans, K. R., \& Cowles, D. (1990b). Relationship Quality in Services Selling: An Interpersonal Influence Perspective. Journal of Marketing, 54(3), 68-81. https://doi.org/10.1177/002224299005400306

Darke, P. R., Ashworth, L., \& Main, K. J. (2009). Great expectations and broken promises: misleading claims, product failure, expectancy disconfirmation and customer distrust. Journal of the Academy of Marketing Science, 38(3), 347-362. https://doi.org/10.1007/s11747-009-0168-7

Dion, P., Easterling, D., \& Miller, S. J. (1995). What is really necessary for successful buyer/seller relationships? Industrial Marketing Management, 24(1), 1-9. https://doi.org/10.1016/0019-8501(94)00025-r 
Doney, P. M., \& Cannon, J. P. (1997). An Examination of the Nature of Trust in Buyer-Seller Relationships. Journal of Marketing, 61(2), 35-51. https://doi.org/10.1177/002224299706100203

Fitzsimons, G. J. (2000). Customer Response to Stockouts. Journal of Customer Research, 27(2), 249-266. https://doi.org/10.1086/314323

Gaston-Breton, C., \& Duque, L. C. (2015). Utilitarian and hedonic promotional appeals of 99ending prices. European Journal of Marketing, 49(1/2), 212-237. https://doi.org/10.1108/ejm-09-2012-0556

Gigerenzer, G., \& Brighton, H. (2009). Homo Heuristics: Why Biased Minds Make Better Inferences. Topics in Cognitive Science, 1(1), 107-143. https://doi.org/10.1111/j.17568765.2008.01006.x

Hausman, A. V., \& Siekpe, J. S. (2009). The effect of web interface features on customer online purchase intentions. Journal of Business Research, 62(1), 5-13. https://doi.org/10.1016/j.jbusres.2008.01.018

Heitmann, M., Lehmann, D. R., \& Herrmann, A. (2007). Choice Goal Attainment and Decision and Consumption Satisfaction. Journal of Marketing Research, 44(2), 234-250. https://doi.org/10.1509/jmkr.44.2.234

Hoyer, W. D. (1984). An Examination of Customer Decision Making for a Common Repeat Purchase Product. Journal of Customer Research, 11(3), 822. https://doi.org/10.1086/209017

Huffman, C., \& Houston, M. J. (1993). Goal-Oriented Experiences and the Development of Knowledge. Journal of Customer Research, 20(2), 190. https://doi.org/10.1086/209343

Karson, E. J., \& Fisher, R. J. (2005). Predicting intentions to return to the Web site: Extending the dual mediation hypothesis. Journal of Interactive Marketing, 19(3), 2-14. https://doi.org/10.1002/dir.20040

Kenkel, W. F., Thibaut, J. W., \& Kelley, H. H. (1959). The Social Psychology of Groups. The American Catholic Sociological Review, 20(4), 345. https://doi.org/10.2307/3709294

Levinthal, D. A., \& Fichman, M. (1988). Dynamics of Interorganizational Attachments: AuditorClient Relationships. Administrative Science Quarterly, 33(3), 345. https://doi.org/10.2307/2392713

Lim Sung Moon. (2015). The Relation between Materialism and Compulsive Buying: Moderated Mediation Effect of Buying Motives and General Decision-Making Style. The Korean 
Journal of Customer and Advertising Psychology, 16(2), 333-362. https://doi.org/10.21074/kjlcap.2015.16.2.333

Loveland, J. M., Lounsbury, J. W., Park, S. H., \& Jackson, D. W. (2015). Are salespeople born or made? Biology, personality, and the career satisfaction of salespeople. Journal of Business \& Industrial Marketing, 30(2), 233-240. https://doi.org/10.1108/jbim-12-2012-0257

Mittal, B., \& Lassar, W. M. (1996). The role of personalization in service encounters. Journal of Retailing, 72(1), 95-109. https://doi.org/10.1016/s0022-4359(96)90007-x

Moorman, C., Deshpande, R., \& Zaltman, G. (1993). Factors Affecting Trust in Market Research Relationships. Journal of Marketing, 57(1), 81. https://doi.org/10.2307/1252059

Morrisson, O., \& Huppertz, J. W. (2010). External equity, loyalty program membership, and service recovery. Journal of Services Marketing, 24(3), 244-254. https://doi.org/10.1108/08876041011040640

Raney, A. A., Arpan, L. M., Pashupati, K., \& Brill, D. A. (2003). At the movies, on the Web: An investigation of the effects of entertaining and interactive Web content on site and brand evaluations. Journal of Interactive Marketing, 17(4), 38-53. https://doi.org/10.1002/dir.10064

Rod, M., \& Ashill, N. J. (2010). Management commitment to service quality and service recovery performance. International Journal of Pharmaceutical and Healthcare Marketing, 4(1), 84-103. https://doi.org/10.1108/17506121011036042

Schlosser, A. E., White, T. B., \& Lloyd, S. M. (2006). Converting Web Site Visitors into Buyers: How Web Site Investment Increases Customer Trusting Beliefs and Online Purchase Intentions. Journal of Marketing, 70(2), 133-148. https://doi.org/10.1509/jmkg.70.2.133

Singh, J., \& Sirdeshmukh, D. (2000). Agency and Trust Mechanisms in Customer Satisfaction and Loyalty Judgments. Journal of the Academy of Marketing Science, 28(1), 150-167. https://doi.org/10.1177/0092070300281014

Stansfield, M. (2004). Electronic Commerce: A Managerial Perspective 2004 (International Edition). International Journal of Information Management, 24(3), 279-280. https://doi.org/10.1016/j.ijinfomgt.2004.02.003

Supphellen, M., \& Nysveen, H. (2001). Drivers of Intention to Revisit the Websites of WellKnown Companies: The Role of Corporate Brand Loyalty. International Journal of Market Research, 43(3), 1-12. https://doi.org/10.1177/147078530104300302 
Svenson, O. (1995). The adaptive decision-maker. John W. Payne, James R. Bettman and Eric J. Johnson, Cambridge: Cambridge University Press, 1993,307 pp. ISBN 0521415055 (hc), ISBN 0521425263 (pb). Journal of Behavioral Decision Making, 8(2), 143-144. https://doi.org/10.1002/bdm.3960080207

Szarota, P. (2007). Book Review: FAMILIES ACROSS CULTURES, edited by James Georgas, John W. Berry, Fons J. R. van de Vijver, Cigdem Kagitcibasi, \& Ype H. Poortinga. Cambridge, UK: Cambridge University Press, 2006, 552 pp. ISBN 13 978-0-521-529877. $\$ 50.00$ (paperback). Journal of Cross-Cultural Psychology, 38(4), 533-535. https://doi.org/10.1177/0022022107302319

Thøgersen, J., Jørgensen, A. K., \& Sandager, S. (2012). Customer Decision Making Regarding a "Green" Everyday Product. Psychology and Marketing, 29(4), 187-197. https://doi.org/10.1002/mar.20514

Todd, P. M., \& Gigerenzer, G. (2000). Précis of Simple heuristics that make us smart. Behavioural and Brain Sciences, 23(5), 727-741. https://doi.org/10.1017/s0140525x00003447

West, P. M., Brown, C. L., \& Hoch, S. J. (1996). Consumption Vocabulary and Preference Formation. Journal of Customer Research, 23(2), 120. https://doi.org/10.1086/209471

Westbrook, R. A., Newman, J. W., \& Taylor, J. R. (1978). Satisfaction/Dissatisfaction in the Purchase Decision Process. Journal of Marketing, 42(4), 54. https://doi.org/10.2307/1250086 